\title{
Penguatan Kelembagaan Ekonomi Masyarakat Pesisir Melalui Pemanfaatan Potensi Lokal Non-Perikanan Di Pulau Giligenting, Sumenep, Madura
}

\author{
Anif Fatma Chawa ${ }^{1}$, Ahmad Imron Rozuli ${ }^{2}$, Rahmi Nurdiani ${ }^{3}$ \\ ${ }^{1}$ Jurusan Sosiologi, Fakultas Ilmu Sosial dan Ilmu Politik, Universitas Brawijaya, Malang, Indonesia \\ ${ }^{2}$ Program Studi Teknologi Hasil Perikanan, Fakultas Ilmu Kelautan dan Perikanan, Universitas \\ Brawijaya, Malang Indonesia \\ Email Korespodensi : anif_chawa@ub.ac.id
}

\begin{abstract}
Abstrak. Pemerintah Indonesia telah menetapkan beberapa program pengembangan masyarakat untuk mencapai kemajuan ekonomi masyarakat pesisir, khususnya kelompok nelayan. Sementara itu, kelompok masyarakat lain yang bermata pencaharian non-perikanan kurang mendapat perhatian. Menyikapi hal tersebut, artikel ini merupakan program intervensi berupa penguatan kelembagaan ekonomi non-perikanan yang telah dilakukan kepada masyarakat Pulau Giligenting, Desa Aenganyar, Kabupaten Sumenep, Madura. Sebagian besar dari mereka hidup dari mata pencaharian non-perikanan dengan membuat kue wafel dan gula aren. Dengan menggunakan Participatori Rural Apraisal (PRA), penelitian ini telah melibatkan masyarakat dalam program-program intervensi, mulai dari mengidentifikasi masalah, merancang program pembangunan hingga melaksanakan program-program tersebut. Untuk lebih jelasnya, program-program tersebut telah dilakukan dalam tiga langkah: pertama, mengidentifikasi potensi ekonomi lokal Pulau Giligenting dari mata pencaharian non-perikanan; kedua, mengenali berbagai masalah yang dihadapi oleh masyarakat yang hidup dari mata pencaharian semacam ini serta menemukan strategi untuk mengatasi masalah tersebut; ketiga, implementasi dari strategistrategi tersebut, salah satunya dengan melakukan program penguatan kelembagaan. Pelaksanaan program ini telah menghasilkan tujuan atau keluaran yang diharapkan antara lain peningkatan kapasitas dan produktivitas, serta pendapatan masyarakat yang hidup dari mata pencaharian non-perikanan.
\end{abstract}

Kata kunci: Masyarakat Pesisir, Participatory Rural Appraisal, Penguatan Kelembagaan, Potensi Lokal Non-Perikanan

Abstract. Indonesia government has established several community developments programs to achieve economic betterment of coastal society, especially the groups of fishermen. Meanwhile, other groups of people who live from non-fisheries livelihood have received less attention. Addressing this issue, an intervention program, which is the institutional strengthening program has been delivered to these people which live in Pulau Gili Pulau Giligenting, Desa Aenganyar, Kabupaten Sumenep, Madura. Most of these people have lived from non-fisheries livelihood by making waffle cake and palm sugar. By employing Participatori Rural Apraisal (PRA), they have been involved in the intervention programs, from identifying problems, designing development programs as well as conducting these programs. To be clear, these programs have been conducted in three steps: first, identifying potential local economic of Pulau Giligenting from non-fisheries livelihood; second, recognizing various problems which have been faced by people who live from this kind of livelihood as well as finding the strategies to address those problems; third, the implementation of these strategies, one of those is by conducting the institutional strengthening program. The implementation of this program has resulted on intended objectives or outputs including increasing capacity and productivity, as well as income of people who live from non-fishery livelihood.

Keywords: Coastal Communities, Institutional Strengthening, non-fisheries livelihood, Participatory Rural Appraisal. 
Jurnal Ilmu Sosial dan Pendidikan

http://ejournal.mandalanursa.org/index.php/JISIP/index

Terakreditasi Peringkat 5 (No. SK: 85/M/KPT/2020)

\section{PENDAHULUAN}

Indonesia masih mempunyai masalah

besar dalam mengatasi isu kemiskinan di wilayah pesisir. Tahun 2015 Badan Pusat Statistik (BPS) melaporkan sebanyak 7,87 juta rumah tangga miskin di Indonesia merupakan masyarakat pesisir. Angka tersebut telah berkontribusi sebesar $25 \%$ pada presentase jumlah total penduduk miskin di Indonesia. Pemerintah telah melakukan berbagai upaya untuk merespon permasalahan tersebut, salah satunya dengan menyusun beberapa program pemberdayaan di wilayah pesisir, seperti program pemberian kartu nelayan dan asuransi nelayan. Akan tetapi, program-program tersebut nampaknya belum dilaksanakan secara total dan menyentuh seluruh nelayan. Sebagai contoh pada program kartu nelayan, hingga saat ini pemerintah hanya menyediakan 1.108 .852 kartu nelayan dari total 8.077.719 rumah tangga nelayan. Pada akhir tahun 2019, Kementerian Kelautan Dan Perikanan (KKP) Republik Indonesia melaporkan bahwa pemberian kartu asuransi nelayan masih menyentuh angka 1.152.177 (Susanto, 2019). Hal ini menunjukan bahwa masih banyak rumah tangga nelayan yang belum dapat menerima manfaat dari kebijakan tersebut. Di samping itu, pada tahun 2017 pemerintah melalui Kementerian Kelautan dan Perikanan juga telah menerbitkan kartu KUSUKA (Kartu Pelaku Usaha Kelautan dan Perikanan) sebagai salah satu program bantuan untuk pelaku usuha dalam mengakses pemodalan. Namun dalam beberapa penelitian menunjukan bahwa manfaat kartu ini masih belum bisa dirasakan oleh para pelaku usuha. Hal ini disebabkan waktu proses dan penerbitan kartu tersebut dirasa rumit dan lama, sehingga membuat para banyak pelaku usaha putus asa (Daniarsyah, 2019; Tiven, Huliselan, \& Lopulalan, 2018).

Pada dasarnya pemberdayaan masyarakat pesisir tidak dapat dilakukan hanya dengan pemberian bantuan-bantuan tunai. Hal ini disebabkan karena kultur masyarakat pesisir masih sangat identik dengan gaya hidup yang
Vol. 4. No. 4 November 2020

p-ISSN: 2598-9944 e- ISSN: 2656-6753

tidak produktif dan tidak efisien, sebagai akibat rendahnya tingkat Pendidikan (Zamzami, 2011). Disisi lain, penggunaan uang bantuan tunai juga hanya akan digunakan oleh sebagian nelayan miskin untuk melunasi bunga hutang pada tengkulak ikan. Penyebabnya tak lain ialah kultur rantai ekonomi nelayan pesisir yang masih identik dengan rantai ekonomi patronklien dengan tengkulak ikan, dimana ini pada akhirnya membuat kehidupan nelayan terjerat oleh 'lingkaran setan' dari kompensasi pinjaman yang sering diberikan oleh seorang tengkulak (Amanah, 2010; Heriyanto, 2013; Indarti \& Wardana, 2013). Kedekatan masyarakat pesisir dengan model kultur ekonomi yang demikian menjadi hambatan tersendiri pada efektifitas program pengentasan kemiskinan yang hanya mengandalkan bantuan-bantuan tunai.

Dengan melihat masalah kultural yang terjadi pada masyarakat pesisir, pada akhirnya beberapa ahli sepakat bahwa pengentasan kemiskinan di wilayah pesisir sebisa mungkin dilaksanakan melalui pemberdayaan masyarakat pesisir yang menciptakan kegiatan-kegiatan ekonomi produktif di daerah yang berbasis potensi dan sumberdaya lokal, serta memiliki pasar yang jelas, sehingga dapat dilakukan secara berkelanjutan serta berdampak bagi masyarakat lokal. Dengan begitu diharapakan dapat tercipta hubungan ekonomi antar kawasan pesisir serta antara pesisir dan perkotaan (Nikijuluw, 2001). Pemberdayaan masyarakat pesisir ini dapat dicapai dengan program pengembangan masyarakat pesisir. Ada banyak penelitian yang telah dilakukan untuk meneliti pelaksanaan program pembangunan ini dalam berbagai perspektif sosiologi, ekonomi, komunikasi pembangunan hingga gender (Amanah, 2010; Daniarsyah, 2019; Heriyanto, 2013; Indarti \& Wardana, 2013; Kurniasari \& Reswati, 2011; Nikijuluw, 2001; Rahim, 2018; Sakinah, Adiputra, \& Outri, 2018; Tampubolon, 2013; Zamzami, 2011). Penelitian ini juga telah menghasilkan output rumusan model dan solusi untuk masalah di mana program pengembangan 
Jurnal Ilmu Sosial dan Pendidikan

http://ejournal.mandalanursa.org/index.php/JISIP/index

Terakreditasi Peringkat 5 (No. SK: 85/M/KPT/2020)

dapat diimplementasikan secara efektif untuk mencapai tujuan pemberdayaan mereka.

Namun, kelemahan dari kebanyakan penelitian pemberdayaan tersebut ialah mereka masih terlalu memfokuskan subjek penelitian kepada nelayan, sehingga output model program pemberdayaan hanya berupa pengembangan usaha perikanan yang menyasar pada nelayan sebagai pelaku ekonomi utamanya. Hal ini tentu mengindahkan kenyataan bahwa sebenarnya pelaku ekonomi masyarakat pesisir bukan hanya terdiri dari seorang nelayan, terdapat banyak pelaku ekonomi laiinya. Oleh karena itu, penelitian ini berusaha mengisi kekosongan studi sebelumnya yaitu mengkaji potensi usaha lokal serta menyusun model pemberdayaan melalui pengembangan peran pemuda di wilayah pesisir, tepatnya di desa Aenganyar, pulau Giligenting, Sumenep, Madura. Penelitian ini juga telah melampaui studi sebelumnya dengan memberikan kontribusi atau intervensi langsung atas permasalahan masyarakat dengan mengoptimalkan potensi non-perikanan di wilayah tersebut. Dengan begitu, penelitian ini berusaha melaksanakan salah satu pendekatan pemberdayaan masyarakat pesisir yaitu, penciptaan lapangan kerja alternatif nonperikanan.

Penelitian ini menggambarkan program pengembangan masyarakat pesisir yang telah dilakukan secara partisipatori. Penelitian menunjukan beberapa tahapan dalam melakukan penguatan kelembagaan ekonomi lokal masyarakat pesisir. Dalam mengurai hal tersebut artikel ini akan dibagi menjadi 3 tujutan; Pertama, melakukan identifikasi potensi ekonomi lokal non-perikanan. Kedua, melakukan pemetaan permasalahan pelaku usaha ekonomi lokal dan menyusun strategi penyelesaian masalah. Ketiga, menerapkan strategi penyelesaian masalah pelaku usaha lokal melalui penguatan kelembagaan ekonomi lokal. Penguatan kelembagaan ekonomi lokal ini bermaksud untuk meningkatkan peran masyarakat lokal lewat lembaga ekonomi lokal
Vol. 4. No. 4 November 2020

p-ISSN: 2598-9944 e- ISSN: 2656-6753

dengan tujuan untuk menopang perekonomian masyarakat lokal itu sendiri.

\section{Penguatan Kelembagaan Ekonomi Lokal}

Secara harfiah istilah "penguatan kelembagaan" mencakup berbagai kegiatan yang bertujuan untuk mengatur kembali atau mereorientasi lembaga agar dapat berfungsi lebih efektif (Jacobs, 1998; Taylor \& Cowiconsult, 1998). Pemberdayaan masyarakat melalui penguatan kelembagaaan ekonomi lokal, adalah salah satu upaya penyederhanaan dan peningkatan ektifitas lembaga ekonomi lokal dengan melibatkan peran masyarakat lokal terhadap lembaga ekonomi. Namun harus digarisbawahi bahwa Lembaga ekonomi lokal yang dimaksud dalam definisi tersebut ialah ikatan sosial yang dibangun berdasarkan "jejaring sosial" (social networking) dari modal sosial masyarakat yang digunakan untuk melakukan pengembangan masyarakat. Menurut Syaukat dan Hendrakusumaatmaja (2004), Penguatan Kelembagaan Ekonomi Lokal ini merupakan hasil dari penguatan modal sosial masyarakat di suatu daerah (lokal) untuk mencapai pertumbuhan ekonomi berkelanjutan, yang akan berdampak pada meningkatnya kesejahteraan ekonomi dan kualitas hidup seluruh masyarakat sekitar. Hal ini secara tidak langsung merupakan upaya peningkatan peran pemerintah lokal, swasta, Lembaga Swadaya Masyarakat, dan masyarakat lokal dalam pengembangan potensi lingkungan sekitar, sehingga mampu digunakan sebagai sarana penunjang peningkatan ekonomi lokal. Oleh karena itu, penguatan kelembagaan ekonomi lokal difokuskan pada upaya peningkatan daya saing (competitiveness), peningkatan pertumbuhan, dan restribusi pertumbuhan tersebut melalui pembentukan usaha kecil dan menengah (SME: small and medium enterprises) dan penciptaan lapangan kerja (Kurniyati, 2013; Yusman \& Atmaja, 2004). Oleh karena itu penguatan kelembagaan juga membutuhkan perhatian pada organisasi serta keterampilan dan sikap anggotanya. Proses ini biasanya disebut dengan pengembangan kapasitas dan 
Jurnal Ilmu Sosial dan Pendidikan

http://ejournal.mandalanursa.org/index.php/JISIP/index

Terakreditasi Peringkat 5 (No. SK: 85/M/KPT/2020)

pengetahuan sumber daya manusia (Alaerts, 2009).

Menurut Eade (2007) pengembangan kapasitas awalnya didasarkan pada berbagai tradisi intelektual dan politik yang umumnya condong ke kiri, tetapi saat ini umumnya digunakan untuk memajukan ekonomi. Bagi Eade (1997) pembangunan adalah proses di mana kerentanan dikurangi dan kapasitas ditingkatkan. Pendekatan pembangunan kapasitas untuk pemberdayaan melibatkan pengidentifikasian kendala yang dialami masyarakat dalam mewujudkan hak-hak dasar mereka, dan menemukan sarana yang tepat untuk memperkuat kemampuan mereka mengatasi penyebab pengucilan dan penderitaan mereka. Dengan demikian, pembedayaan masayarakat melalui penguatan kelembagaan ekonomi lokal harus dimulai melalui pengembangan kapasitas dan pengetahuan terhadap agen yang akan terlibat dalam Lembaga tersebut. Hal ini juga berarti pada upaya menigkatkan kemampuan, skill, pengetahuan masyarakat dalam mengidentifikasi permasalahan dan menemukan solusi yang dapat menghasilkan kemandirian dan keswadayaan masyarakat (Eade, 2007). Rubin dan Irene (1992) mendefinisikan kegiatan ini sebagai upaya mengidentifikasi kekurangan yang ada pada diri seseorang dan upaya meningkatkan kekurangan tersebut menjadi sebuah kelebihan.

\section{METODE}

Penelitian ini dilaksanakan dengan pendekatan Participatory Rural Appraisal (PRA), dimana melalui pendekatan ini peneliti memberi kesempatan kepada masyarakat lokal untuk mengekspresikan, meningkatkan, berbagi serta menganalisis pengetahuan mereka tentang kondisi kehidupan mereka sendiri yang kemudian digunakan untuk bahan diskusi mereka dalam menyusun perencanaan. Pendekatan ini memiliki kelebihan untuk memunculkan analisis yang tidak terduga dari masyarakat lokal, karena asumsi dalam
Vol. 4. No. 4 November 2020

p-ISSN: 2598-9944 e- ISSN: 2656-6753

pendekatan ini ialah "masyarakat lokal sebagai peneliti dirinya sendiri” (Chambers, 1994c). Melalui pendekatan ini masyarakat lokal akan menikmati pembelajaran kreatif yang muncul dari penyampaian pengetahuan dan realitas mereka sendiri. Masyarakat lokal tidak hanya berbagi pengetahuan dengan orang luar. Mereka sendiri belajar lebih banyak tentang apa yang mereka ketahui, dan bersama-sama membangun pengetahuan lebih dari yang diketahui oleh mereka sendiri (Bar-on \& Prinsen, 1999; Chambers, 1994b, 1994a; Herbert \& Irene, 1992; Solano Lara, Fernández Crispín, \& López Téllez, 2018). Proses tersebut secara tidak langsung dapat memberdayakan mereka, dimana ini dengan meningkatkan kemampuan mereka melakukan analisis pada dunia mereka sendiri dan mengarahkan ke perencanaan serta tindakan mereka selanjutnya. Dengan demikian bukan realitas orang luar yang ditransfer dan dipaksakan kepada masyarakat lokal, tetapi realitas masyarakat lokal yang diungkapkan, dibagikan, dan diperkuat oleh mereka sendiri(Chambers, 1994b). Dalam pembalikan terakhir ini, yang diperhitungkan adalah realitas masyarakat lokal daripada profesional luar.

Meski pendekatan PRA sangat terfokus pada masyarakat lokal itu sendiri, akan tetapi PRA telah menunjukan validitas dan reliabilitas yang lebih baik dibandingkan dengan data dari metode yang lebih tradisional. Dalam pendekatan PRA, validitas mengacu pada kedekatan suatu temuan dengan kenyataan, dan reliabilitas mengacu pada keteguhan temuan (Chambers, 1994c). Sebab proses validitas dan reliabilitas telah muncul secara satu kesatuan pada saat pengumpulan data melalui Forum Group Discussion (FGD). FGD adalah suatu proses pengumpulan informasi suatu masalah tertentu yang sangat spesifik melalui diskusi kelompok yang melibatkan minimal 6 orang. Melalui teknik pengumpulan data ini, proses pengecekatan validitas dan reliabilitas data berjalan secara mandiri melalui diskusi antar masyarakat lokal (Chambers, 1994a; Irwanto, 1998). Oleh karena itu, dalam penelitian ini FGD 
Jurnal Ilmu Sosial dan Pendidikan

http://ejournal.mandalanursa.org/index.php/JISIP/index

Terakreditasi Peringkat 5 (No. SK: 85/M/KPT/2020)

dilakukan beberapa kali dengan melibatkan masyarakat lokal dari beberapa elemen seperti; Perangkat Desa, Pelaku Usaha non-perikanan, serta Pemuda di pulau Giligenting. Pemilihan subjek yang terlibat dalam FGD tersebut diambil melalui teknik purposive yang memungkinkan peneliti memilih berdasarakn pertimbangan pengetahuan atau keahlian spesifik mereka dalam bidang penelitian.

Dalam pelaksanaan FGD ini peneliti mengajak masyarakat lokal Giligenting untuk membuat tabel analisis SWOT. Analisis SWOT ini berguna untuk memetakan Strength (kekuatan), Weakness (kelemahan), Opportunity (peluang) dan Threats (ancaman) yang ada pada lingkungan masyarakat serta menginventarisasi faktor-faktor tersebut dalam strategi perencanaan yang dipakai sebagai dasar untuk menentukan langkah-langkah perbaikan yang diperlukan dalam pengembangan (Yoeti, 1996). Kemudian dari tabel tersebut peneliti akan membantu untuk membuatkan matriks dan kuadran SWOT untuk mengetahui strategi dasar pemecahan masalah yang dapat diterapkan secara kualitatif. Strategi inilah yang kemudian dijadikan dasar tindak lanjut untuk melaksanakan pemberdayaan masyarakat pesisir di pulau Giligenting, sehingga program pemberdayaan disini dilaksanakan secara Bottom-up melalui ekstraksi hasil pengetahuan dan analisis masyarakat lokal itu sendiri.

\section{HASIL DAN PEMBAHASAN}

\section{Identifikasi Potensi Ekonomi Lokal Non- perikanan.}

Hal pertama yang dilakukan dalam penelitian pemberdayaan ini adalah melakukan identifikasi potensi ekonomi lokal nonperikanan. Dalam membangun program pemberdayaan kegiatan identifikasi ini menjadi penting sebagai salah satu pendekatan yang membantu dalam membentuk klaster lembaga ekonomi spasial yang mapan (NowakowskaGrunt \& Wiśniewska-Sałek, 2014; Taranova, Gunko, Alekseeva, Bunchikov, \& Kurennaya, 2015). Dalam hal ini metodologi PRA dapat
Vol. 4. No. 4 November 2020

p-ISSN: 2598-9944 e- ISSN: 2656-6753

berperan sebagai metode yang dapat melakukan perbandingan potensi berbagai sektor perekonomian secara partisipatif melalui beberapa tools, salah satunya ialah social mapping. Dalam beberapa kasus, Social Mapping telah menjadi alat partisipatif yang efektif digunakan untuk mendokumentasikan dan memberi umpan balik pengetahuan dan aspirasi masyarakat lokal ataupun pemangku kepentingan. Selain itu, social mapping juga terbukti efektif digunakan sebagai participatory tools dalam penelitian di wilayah pesisir. Klarifikasi nilai-nilai menggunakan social mapping telah memberikan wawasan yang lebih baik untuk memahami masyarakat lokal dalam mengidentifikasi nilai-nilai penting di wilayah pesisir seperti pariwisata, estetika, aspek budaya dan potensi ekonomi (Rockloff \& Lockie, 2004).

Identifikasi potensi ekonomi lokal nonperikanan ini dilakukan melalui FGD yang melibatkan aparat desa dan pemuda desa Aenganyar dengan menggunakan tools Social Mapping. Social Mapping ini bertujuan untuk memetakan persebaran produsen atau pelaku ekonomi produk lokal yang masih aktif hingga saat ini. Selain itu, Social Mapping ini juga berfungsi untuk mengetahui tempat-tempat yang selama ini menjadi tempat pemasaran bagi produk lokal tersebut. Dengan PRA, social mapping dalam penelitian ini dilakukan dengan menyediakan kertas karton kosong beserta peralatan alat tulis, kemudian masyarakat lokal diajak untuk membuat peta buta dan mulai memetakan persebaran pelaku ekonomi produk lokal non-perikanan yang memiliki potensi untuk diberdayakan. Berikut merupakan hasil Social Mapping yang telah dibuat oleh masyarakat pesisir pulau Giligenting; 
Jurnal Ilmu Sosial dan Pendidikan

http://ejournal.mandalanursa.org/index.php/JISIP/index

Terakreditasi Peringkat 5 (No. SK: 85/M/KPT/2020)

Gambar 1 Hasil Social Mapping yang dilakukan oleh Masyarakat

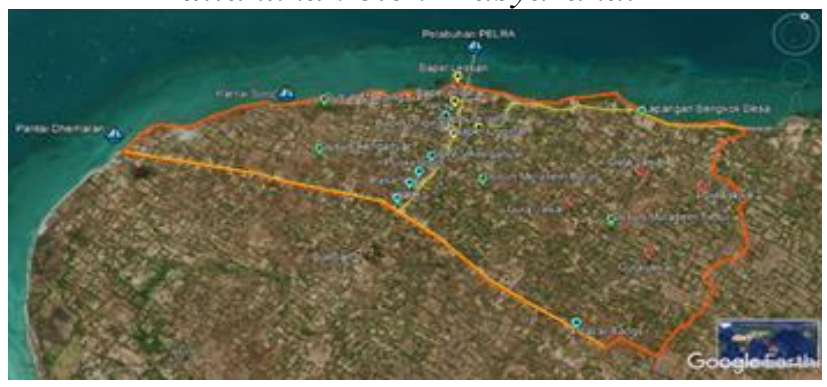

(Sumber: Data PRA Peneliti, 2020)

Gambar di atas merupakan hasil mentah social mapping yang dilakukan oleh para pemuda dan aparat desa Aenganyar, Pulau Giligenting. Dari hasil di atas peneliti kemudian mensimulasikannya melalui Google Earth, berikut hasil simulasi pemetaan melalui google earth.

Gambar 2 Hasil Simulasi Social Mapping via Google Earth

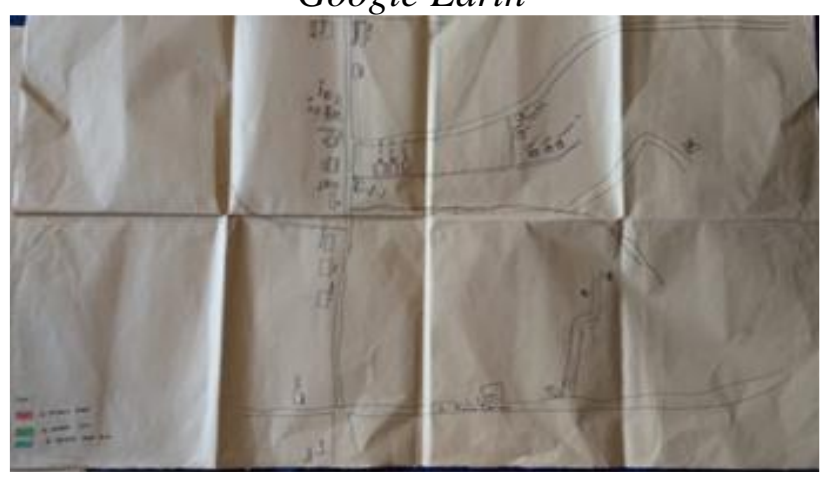

(Sumber: Data PRA Peneliti, 2020)

Hasil di atas menunjukan bahwa saat ini terdapat 3 jenis usaha non-perikanan yang telah berkembang di pulau giligenting yaitu Kue Bapel, Gula Jawa dan Abon Ikan. Dari hasil social mapping juga diketahui bahwa terdapat 10 pelaku produsen kue bapel, 4 pelaku produsen gula jawa dan 1 pelaku produsen abon ikan yang masih aktif. Keseluruhan pelaku produsen produk lokal non-perikanan tersebut tersebar secara merata di seluruh dusun yang ada di desa Aenganyar, hanya abon ikan yang bertempat di satu dusun yaitu di dusun Aenganyar. Jangkauan tempat penjualan produk lokal selama ini juga masih mengandalkan 2 pasar serta tempat kerumunan seperti Sekolah
Vol. 4. No. 4 November 2020

p-ISSN : 2598-9944 e- ISSN: 2656-6753

dan Puskesmas. Keberadaan pantai juga belum dioptimalkan sebagai tempat pemasaran produk, hal ini disebabkan karena desa belum membuka pantai sebagai tempat umum.

Disamping itu hasil social mapping juga menunjukan karakteristik lokasi persebaran pelaku produk lokal, sebagaimana pelaku ekonomi kue bapel berpusat di bagian selatan dan gula jawa berpusat di bagian utara desa Aenganyar. Hal ini menunjukan bahwa pelaku produk lokal juga terbagi berdasarkan karakteristik lokasi. Bagian utara desa merupakan lokasi yang masih dipadati hutan dan perkebuanan masyarakat, sehingga lokasi persebaran produsen gula jawa juga mengikuti karateristik tersebut, sebab gula jawa terbuat dari bahan baku buah siwalan yang ditanam diperkebunan. Sedangkan bagian selatan merupakan lokasi pemukiman masyarakat dan pertokoan, sehingga lokasi persebaran produsen kue bapel berada di daerah tersebut. Dengan demikian dapat disimpulkan bahwa persebaran pelaku produsen produk lokal berkerumun sesuai dengan kedekatan dalam mendapatkan sumber daya bahan baku pembuatan produk lokal tersebut.

\section{Pemetaan Permasalahan Pelaku Usaha Ekonomi Lokal dan Penyusunan Strategi Penyelesaian Masalah}

Dari temuan 3 potensi ekonomi non perikanan di atas, hasil FGD menunjukan bahwa hanya kue bapel yang memiliki potensi untuk lebih mudah dikembangkan. Hal ini dikarenakan kue bapel memiliki bahan baku sumber daya yang lebih mudah dijangkau daripada Gula Jawa dan Abon ikan. Bahan baku gula jawa berasal dari pohon buah siwalan yang hanya berbuah saat musim kemarau, begitupula dengan abon ikan yang sangat bergantung pada hasil penangkapan ikan yang tidak menentu. Oleh karena itu, bapel lebih memiliki peluang untuk dikembangkan sebagai penghasilan ekonomi lokal alternatif. Namun sebelum itu, perlu dilakukan pemetaan permasalahan terkait usaha kue bapel yang selama ini berjalan. Karena bagaimanapun jika kesetaraan adalah tujuan 
Jurnal Ilmu Sosial dan Pendidikan

http://ejournal.mandalanursa.org/index.php/JISIP/index

Terakreditasi Peringkat 5 (No. SK: 85/M/KPT/2020)

pembangunan, maka intervensi harus mengatasi penyebab kelemahan masyarakat dan mengenali sumber kekuatan mereka, dan memahami hubungan dinamisnya (Eade, 1997). Peneliti disini mengundang para pelaku ekonomi kue bapel, pemuda dan aparat desa untuk melakukan pemetaan permasalahan dengan menggunakan tools tabel SWOT secara mandiri, sebagaimana PRA melihat masyarakat sebagai komunitas mampu memetakan, membuat model, peringkat, skor, diagram dan menganalisis lebih banyak dan lebih baik dari yang diharapkan (Chambers, 1994b; Eade, 2007). Berikut hasil pemetaan yang telah dilakukan oleh masyarakat;

Tabel 1 Analisis SWOT Produk Kue Bapel

\begin{tabular}{|c|c|c|c|}
\hline Kekuatan & Kelemahan & Peluang & Ancaman \\
\hline 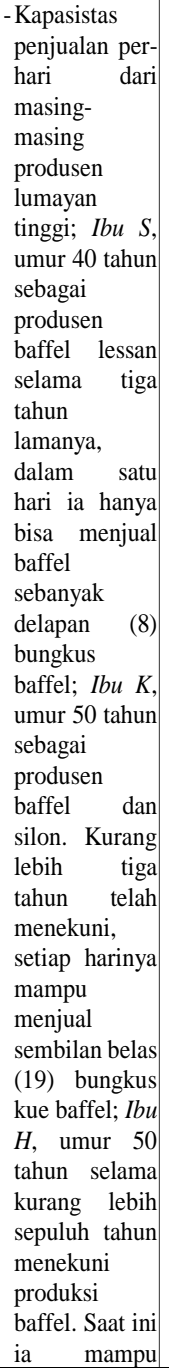 & $\begin{array}{l}\text { - Cita rasa buffel } \\
\text { tidak mampu } \\
\text { bertahan dalam } \\
\text { jangka waktu } \\
\text { lama. } \\
\text { - Cita rasa buffel } \\
\text { yang diandalkan } \\
\text { sebagai produk } \\
\text { oleh-oleh khas } \\
\text { lokal belum } \\
\text { mempunyai cita } \\
\text { rasa yang paten, } \\
\text { artinya antara } \\
\text { penjual buffel } \\
\text { satu dengan } \\
\text { lainnya } \\
\text { memiliki cita } \\
\text { rasa yang } \\
\text { berbeda. } \\
\text { - Selama ini } \\
\text { produk buffel } \\
\text { belum pernah } \\
\text { mengalami } \\
\text { inovasi produk. } \\
\text { - Kemasan yang } \\
\text { hanya } \\
\text { dibungkus } \\
\text { dengan kresek } \\
\text { atau mika } \\
\text { membuat kue } \\
\text { buffel terkesan } \\
\text { biasa aja sebagai } \\
\text { produk oleh- } \\
\text { oleh. } \\
\text { - Pemasaran yang } \\
\text { kurang massif } \\
\text { dan tidak ada } \\
\text { bantuan dari } \\
\text { desa untuk } \\
\text { mempromosikan } \\
\text { lebih luas. }\end{array}$ & $\begin{array}{l}\text { - Sudah ada } \\
\text { BUMDes yang } \\
\text { seharunya } \\
\text { mampu } \\
\text { memfasilitasi } \\
\text { aktifitas } \\
\text { ekonomi yang } \\
\text { melibatkan } \\
\text { produk lokal } \\
\text { - Banyaknya para } \\
\text { pemuda yang } \\
\text { bisa } \\
\text { dimanfaatkan } \\
\text { untuk } \\
\text { melakuakan } \\
\text { inovasi produk } \\
\text { - Banyaknya para } \\
\text { penduduk yang } \\
\text { merantau dapat } \\
\text { dimaksimalkan } \\
\text { untuk } \\
\text { mempromosikan } \\
\text { produk lokal } \\
\text { lebih jauh. } \\
\text { - Banyaknya } \\
\text { tempat wisata } \\
\text { yang bisa } \\
\text { dimanfaatkan } \\
\text { untuk } \\
\text { pengembangan } \\
\text { pemasaran. } \\
\text { - Pengoptimalan } \\
\text { pemasaran } \\
\text { melalui media } \\
\text { sosial. }\end{array}$ & $\begin{array}{l}\text { - Harga bahan } \\
\text { baku yang } \\
\text { dapat } \\
\text { melambung } \\
\text { tinggi } \\
\text { sewaktu- } \\
\text { waktu dapat } \\
\text { mengurangi } \\
\text { laba para } \\
\text { produsen } \\
\text { buffel. } \\
\text { - Belum adanya } \\
\text { kelembagaan } \\
\text { ekonomi yang } \\
\text { terpusat } \\
\text { membuat } \\
\text { produsen } \\
\text { buffel } \\
\text { bersaing } \\
\text { secara bebas } \\
\text { antara satu dan } \\
\text { lainnya. } \\
\text { - Belum adanya } \\
\text { SOP atau } \\
\text { penyatuan } \\
\text { resep } \\
\text { membuat cita } \\
\text { rasa buffel } \\
\text { yang dapat } \\
\text { berubah tiap } \\
\text { produksi. } \\
\text { - Tidak adanya } \\
\text { kesatuan cita } \\
\text { rasa yang } \\
\text { tetap, dapat } \\
\text { membuat } \\
\text { wisatawan } \\
\text { kecewa ketika } \\
\text { membeli kue } \\
\text { buffel sebagai } \\
\text { produk oleh- } \\
\text { oleh. Hal ini } \\
\text { dapat } \\
\text { mempengaruhi } \\
\text { penjualan ke }\end{array}$ \\
\hline
\end{tabular}

(Sumber: Analisis Data PRA Peneliti, 2020)
Vol. 4. No. 4 November 2020

p-ISSN : 2598-9944 e- ISSN: 2656-6753
Hasil pemetaan permasalahan melalui tabel SWOT di atas digunakan untuk konsep dasar pengembangan produksi kue buffel. Dengan begitu dapat disusun berbagai strategi untuk mengembangkan atau memperbaiki permasalahan, misalnya, strategi yang memanfaatkan kekuatan dan kesempatan secara terbuka; strategi yang mengatasi ancaman yang muncul; atau strategi memperbaiki kelemahan. Dalam tabel SWOT di atas yang meliputi aspek kekuatan (S), kelemahan (W), peluang (O) dan ancaman (T), keempatnya memiliki keterkaitan satu dengan yang lain. Dengan adanya keterkaitan tersebut maka akan diperoleh beberapa strategi atau konsep dasar pengembangan yang dapat digunakan dalam pengembangan dalam produksi kue buffel baik fisik maupun non fisik. Penentuan konsep dasar pengembangan dilakuan berdasarkan analisis SWOT dengan melakukan penilaian (pembobotan) menggunakan analisis faktor internal (IFAS/ Internal Factor Analysis Summary) yang terdiri dari kekuatan dan kelemahan serta faktor eksternal (EFAS/ External Factor Analysis Summary) yang terdiri dari peluang dan ancaman. Hasil dari penilaian (pembobotan) tersebut kemudian ditampilkan dalam bentuk kuadran yang akan menentukan strategi pengembangan selanjutnya (Yoeti, 1996).

Penilaian dilakukan pada setiap aspek SWOT dengan memberi bobot antara 0,00 hingga 1,00, dimana jika aspek-aspek masingmasing faktor (internal/eksternal) dijumlahkan akan menghasilkan bobot 1. Setelah melakukan pembobotan, diberikan rating dimana rating ini menunjukkan tingkat kepentingan masingmasing aspek. Rating yang diberikan yaitu berdasarkan kriteria yang telah dibuat dimana masing-masing aspek memiliki 3 kriteria, kriteria pertama memiliki rating 1; kriteria kedua memiliki rating 2; kriteria ketiga memiliki rating 3. Berikut hasil matrik kriteria dari hasil SWOT yang telah dibuat oleh masyarakat pulau giligenting; 
Jurnal Ilmu Sosial dan Pendidikan

http://ejournal.mandalanursa.org/index.php/JISIP/index

Terakreditasi Peringkat 5 (No. SK: 85/M/KPT/2020)
Vol. 4. No. 4 November 2020

p-ISSN : 2598-9944 e- ISSN: 2656-6753
Tabel 2 Matriks Kriteria Analisis IFAS Produksi Kue Baffel

\begin{tabular}{|c|c|c|c|}
\hline Faktor & Kriteria & Bobot & Rating \\
\hline \multirow{5}{*}{ Kekuatan } & $\begin{array}{l}\text { Kapasistas penjualan per-hari dari } \\
\text { masing-masing produsen lumayan } \\
\text { tinggi }\end{array}$ & 0,23 & 3 \\
\hline & $\begin{array}{l}\text { Baffel telah dijual dibeberapa } \\
\text { tempat seperti pasar, pinggir jalan, } \\
\text { dan dititipkan di warung. }\end{array}$ & 0,15 & 2 \\
\hline & $\begin{array}{l}\text { Baffel banyak terjual ketika ada } \\
\text { pendatang dari luar pulau dan } \\
\text { menjadikan baffel sebagai produk } \\
\text { oleh-oleh. }\end{array}$ & 0,23 & 3 \\
\hline & $\begin{array}{l}\text { Saat sebelum puasa, puasa, dan } \\
\text { pasca puasa penjualan beffel } \\
\text { meningkat hampir tiga kali lipat. }\end{array}$ & 0,23 & 3 \\
\hline & $\begin{array}{l}\text { keuntungan yang didapat satu } \\
\text { bungkus baffel sebesar lima ribu } \\
\text { rupiah (baffel merah) dan tiga ribu } \\
\text { rupiah (baffel lessan) }\end{array}$ & 0,15 & 3 \\
\hline & & 1 & \\
\hline \multirow{6}{*}{ Kelemahan } & $\begin{array}{l}\text { Cita rasa buffel tidak mampu } \\
\text { bertahan dalam jangka waktu lama. }\end{array}$ & 0,23 & 3 \\
\hline & $\begin{array}{l}\text { Cita rasa buffel yang diandalkan } \\
\text { sebagai produk oleh-oleh khas lokal } \\
\text { belum mempunyai cita rasa yang } \\
\text { paten, antara penjual buffel satu } \\
\text { dengan lainnya memiliki 3cita rasa } \\
\text { yang berbeda. }\end{array}$ & 0,15 & 3 \\
\hline & $\begin{array}{l}\text { Selama ini produk buffel belum } \\
\text { pernah mengalami inovasi produk. }\end{array}$ & 0,23 & 3 \\
\hline & $\begin{array}{l}\text { Kemasan yang hanya dibungkus } \\
\text { dengan kresek atau mika membuat } \\
\text { kue buffel terkesan biasa aja } \\
\text { sebagai produk oleh-oleh yang } \\
\text { murah. }\end{array}$ & 0,15 & 3 \\
\hline & $\begin{array}{l}\text { Pemasaran yang kurang massif dan } \\
\text { tidak ada bantuan dari desa untuk } \\
\text { mempromosikan lebih luas. }\end{array}$ & 0,23 & 3 \\
\hline & & 1 & \\
\hline
\end{tabular}

(Sumber: Analisis Data PRA Peneliti, 2020)

Tabel 3 Matriks Kriteria Analisis EFAS

Produksi Kue Baffel

\begin{tabular}{|c|c|c|c|c|}
\hline Faktor & Kriteria & Bobot & Rating & $\mathrm{Bo}$ \\
\hline \multirow{5}{*}{ Peluang } & $\begin{array}{l}\text { Sudah ada BUMDes yang seharunya } \\
\text { mampu memfasilitasi aktifitas ekonomi } \\
\text { yang melibatkan produk lokal }\end{array}$ & 0,21 & 3 & \\
\hline & $\begin{array}{l}\text { Banyaknya para pemuda yang bisa } \\
\text { dimanfaatkan untuk melakuakan inovasi } \\
\text { produk }\end{array}$ & 0,14 & 3 & \\
\hline & $\begin{array}{l}\text { Banyaknya para penduduk yang } \\
\text { merantau dapat dimaksimalkan untuk } \\
\text { mempromosikan produk lokal lebih jauh. }\end{array}$ & 0,21 & 2 & \\
\hline & $\begin{array}{l}\text { Banyaknya tempat wisata yang bisa } \\
\text { dimanfaatkan untuk pengembangan } \\
\text { pemasaran. }\end{array}$ & 0,21 & 3 & \\
\hline & $\begin{array}{l}\text { Pengoptimalan pemasaran melalui media } \\
\text { sosial. }\end{array}$ & 0,21 & 3 & \\
\hline & & 1 & & \\
\hline \multirow{5}{*}{ Ancaman } & \begin{tabular}{|l} 
Harga bahan baku yang dapat \\
melambung tinggi sewaktu-waktu dapat \\
mengurangi laba para produsen buffel.
\end{tabular} & 0,30 & 3 & \\
\hline & $\begin{array}{l}\text { Belum adanya kelembagaan ekonomi } \\
\text { yang terpusat membuat produsen buffel } \\
\text { bersaing secara bebas antara satu dan } \\
\text { lainnya. }\end{array}$ & 0,30 & 3 & \\
\hline & \begin{tabular}{|l|}
$\begin{array}{l}\text { Belum adanya SOP atau penyatuan resep } \\
\text { membuat cita rasa buffel yang dapat } \\
\text { berubah tiap produksi. }\end{array}$ \\
\end{tabular} & 0,20 & 2 & \\
\hline & $\begin{array}{l}\text { Tidak adanya kesatuan cita rasa yang } \\
\text { tetap, dapat membuat wisatawan kecewa } \\
\text { ketika membeli kue buffel sebagai } \\
\text { produk oleh-oleh. Hal ini dapat } \\
\text { mempengaruhi penjualan ke wisatawan } \\
\text { selanjutnya. }\end{array}$ & 0,20 & 2 & \\
\hline & & 1 & & \\
\hline
\end{tabular}

(Sumber: Hasil Analisis data PRA Peneliti, 2020)

Dari hasil pembobotan di atas, maka dapat dilihat posisi dalam kuadran strategi analisis FAS-EFAS yang dihitung berdasarkan perhitungan di bawah ini:

\section{X= POTENSI - MASALAH}

$=2,85-3$

$=-0,15$

Y = PELUANG - ANCAMAN

$=2,79-2,20$

$=0,58$

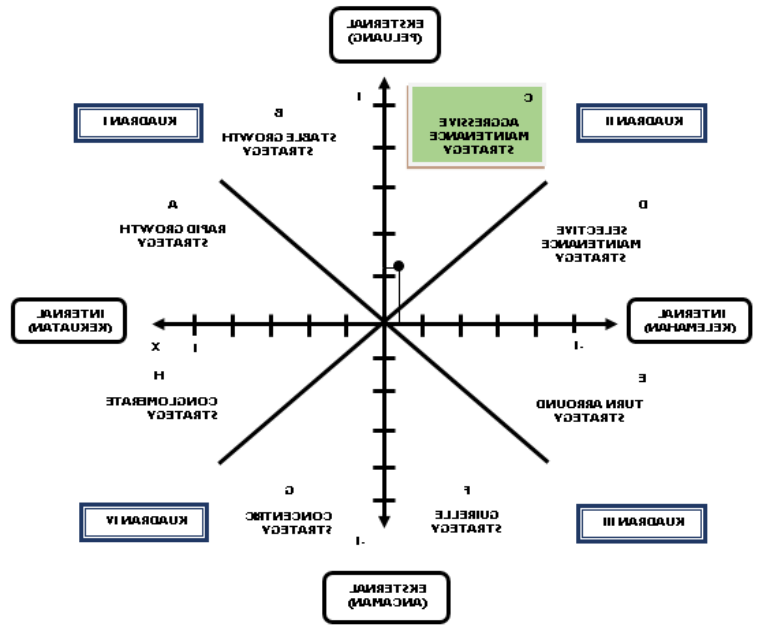

Gambar 3. Diagram Kuadran Analisis IFAS EFAS Produksi Kue Buffel

(Sumber: Hasil Analisis Data PRA Peneliti, 2020)

Berdasarkan hasil analisis tersebut, maka dapat disimpulkan bahwa strategi yang dihasilkan berada pada kuadran II C, yaitu Agresive Maintanance Strategy. Hal ini berarti strategi pengembangan disusun dengan melaksanakan pengembangan secara agresif dan aktif. Ini dapat dilakukan dengan mengoptimalkan peluang untuk mengatasi pemasalahan internal. Sesuai dengan kendala yang dihadapi pada produksi kue buffel, strategi ini cocok karena bergerak secara aktif dan agresif. Strategi yang dapat dilakukan yaitu:

1. Pembentukan kelembagaan satu pintu pelaku usaha kue bapel.

2. Pemanfaatan SDM pemuda dalam pengembangan inovasi produk kue bapel 
Jurnal Ilmu Sosial dan Pendidikan

http://ejournal.mandalanursa.org/index.php/JISIP/index

Terakreditasi Peringkat 5 (No. SK: 85/M/KPT/2020)

dari segi cita rasa, pengemasan hingga pemasaran.

3. Pengoptimalan BUMDes dalam program pendukung produk lokal melalui bantuan dan penyediaan baha baku.

4. Peningkatan penjualan kue baffel hingga ke luar pulau dengan media promosi online

5. Pengoptimalan cita rasa antara pelaku usaha kue bapel.

\section{Penerapan Strategi Penyelesaian Masalah melalui Program PERTIWI}

Setelah tersusun rencana strategi untuk mengatasi permasalahan, maka peneliti mulai menerapkan strategi tersebut sebagai bentuk intervensi penyelesaian masalah. Ini merupakan ide utama Participatory Rural Appraisal (PRA) yang berupaya menawarkan cara untuk memahami pembangunan dan intervensi bantuan dengan cara yang lebih dinamis, terpilah, dan sistemik, sehingga mampu berimplikasi jangka panjang bagi masyarakat secara keseluruhan (Chambers, 1994c; Eade, 1997). Program PERTIWI merupakan kepanjangan dari Penguatan Ekonomi Rakyat Tetap Ingat Wilayah Induk. Program ini merupakan respon intervensi dari hasil pemetaan masalah yang sudah dilakukan oleh masyarakat lokal. Sebagaimana dari hasil penyusunan strategi yang telah dianalisis mmenunjukan bahwa penyelesaian permasalahan dapat dilakukan melalui pembentukan kelembagaan yang mengatur dan mengembangkan kegiatan ekonomi produk kue bapel agar lebih efektif dan efisien. Oleh karena itu, program PERTIWI adalan program yang berfungsi sebagai tempat untuk menerapkan strategi tersebut. PERTIWI dibangun berdasarkan hasil analisis strategi, sehingga ia beroperasi dengan memanfaatkan dan mengkolaborasikan potensi pemuda dan pemerintah desa untuk mengoptimalkan potensi porduk lokal non-perikanan, sebagaimana rekomendasi dari analisis strategi.

Program PERTIWI ini dijalankan dengan bentuk organisasi bernama PERTIWI.
Vol. 4. No. 4 November 2020

p-ISSN: 2598-9944 e- ISSN: 2656-6753

Melalui organisasi ini kemudian akan dilakukan pengauatan kelembagaan ekonomi dengan memusatkan rantai ekonomi produk lokal menjadi tersentral. Pada model kelembagaan ini pelaku ekonomi khususnya kue bapel akan mendapatkan bahan baku dari BUMDes. BUMDes sebagai penyedia bahan baku kemudian membeli hasil produk lokal tersebut dengan harga yang telah disepakati bersama. Kemudian hasil produk lokal ini akan diteruskan oleh BUMDes ke PERTIWI untuk dikemas dan di inovasi kembali, yang selanjutnya akan didistribusikan ke jaringan pasar yang lebih luas. Hasil dari penjualan akan dibagi berdasarkan kesepakatan profit share antara BUMDes, Produsen, dan PERTIWI. Berikut bagan model kelembagaan ekonomi sentral berbasis organisasi pemuda PERTIWI.

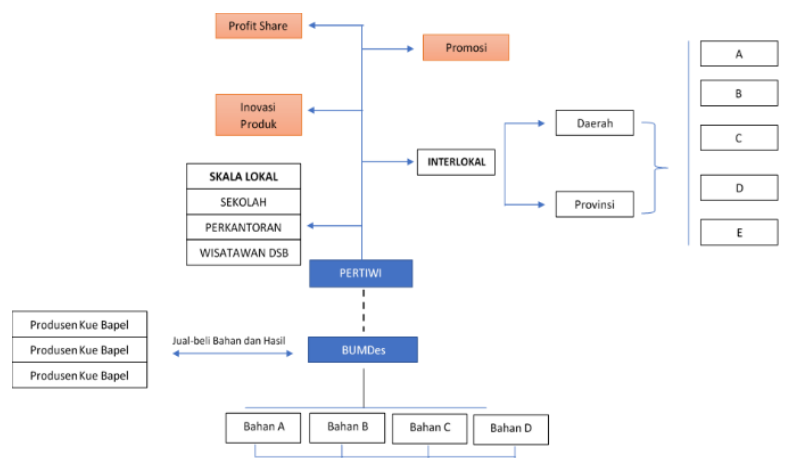

Gambar 4. Bagan Model Kelembagaan Ekonomi PERTIWI

(Sumber: Data PRA Peneliti, 2020)

Dalam menerapkan kelembagaan di atas terdapat beberapa tahapan yang harus dilakukan. Tahap pertama adalah mempersiapkan SDM yang akan terlibat dalam kelembagaan. Seperti dijelaskan sebelumnya, salah satu yang SDM yang dipersiapkan dalam pembentukan kelembagaan ini adalah pemuda di Desa Aenganyar, Kecamatan Giligenting. Dalam tahap pertama ini peneliti melakukan kegiatan capacity building kepada 15 pemuda yang terlibat dalam kelembagaan. Program capacity building ini bertujuan untuk memperkuat kapasitas masyarakat agar mampu menentukan nilai dan prioritas mereka sendiri serta untuk 
Jurnal Ilmu Sosial dan Pendidikan

http://ejournal.mandalanursa.org/index.php/JISIP/index

Terakreditasi Peringkat 5 (No. SK: 85/M/KPT/2020)

mengatur tindakan diri mereka sendiri (Eade, 1997).

Terdapat beberapa 3 program capacity building yang dilakukan dalam penelitian ini. Pertama, program capacity building pelatihan Kepemimpinan dan Keorganisasian. Pelatihan keorganisasian ini bertujuan untuk meningkatkan skill keorganisasian para pemuda. Dalam kegiatan ini peneliti juga melakukan pelatihan dengan model partisipatori. Sesi pertama, peserta yang merupakan para pemuda Desa Aenganyar diajak berdiskusi mengenai pendapat mereka tentang definisi organisasi dan bagaimana cara menjalankan organsasi. Peneliti mengajak para peserta untuk melihat organisasi dilingkungan mereka seperti Karang Taruna, Tim Sepak Bola, Tim Voli dsb. Dari contoh tersebut peneliti mengajak peserta untuk memahami esensi organisasi. Kemudian setelahnya peserta diajak untuk memahami kepanjangan dari PERTIWI, serta diajak untuk memikirkan kira-kira apa maksud dan tujuan organisasi PERTIWI jika dilihat dari kepanjangan tersebut. Setelah peserta dapat menyusun maksud dan tujuan, peserta diajak untuk memadatkan maksud dan tujuan kelembagaan untuk digunakan sebagai visi dan misi organisasi. Gambar 3 merupakan akumulasi opini yang ditulis oleh para peserta mengenai maksud dan tujuan serta visi dan misi;
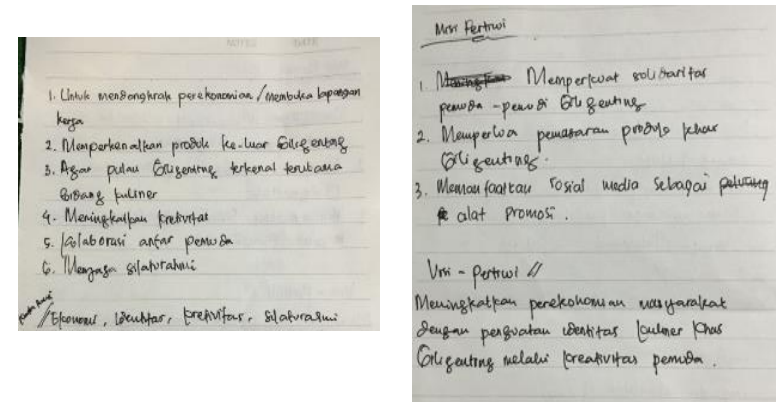

Gambar 5. Hasil Diskusi Visi dan Misi Organiasi yang dilakukan oleh Masyarakat

(Sumber: Data PRA Peneliti, 2020)

Dengan demikian, kegiatan pelatihan keorganisasian ini setidaknya menghasilkan beberapa output:
Vol. 4. No. 4 November 2020

p-ISSN: 2598-9944 e- ISSN: 2656-6753

1. Para pemuda mampu menyatukan pendapat untuk dijadikan rumusan maksud dan tujuan organisasi PERTIWI secara mandiri dan kolektif sebagai berikut:

- Untuk mendongkrak perekonomian dan membuka lapangan pekerjaan

- Untuk mengenalkan produk kuliner lokal ke luar pulau Giligenting

- Untuk Meningkatkan kreatifitas pemuda

- Untuk meningkatkan kolaborasi serta kerja sama antar pemuda

- Untuk menjaga silaturahmi dan solidaritan antar pemuda

2. Para pemuda mampu merumuskan visi dan misi organisasi PERTIWI secara mandiri, sebagai berikut;

- Visi : Meningkatkan perekenomian masyarakat dengan penguatan identitas kuliner khas Giligenting melalui kreativitas pemuda

- Misi : 1. Memperkuat pondasi solidaritas pemuda-pemudi Giligenting

2. Memperluas pemasaran produk khas Giligenting

3. Memanfaatkan sosial media sebagai alat promosi

Kedua, peneliti melakukan program capacity building pelatihan strategi semasaran dan pemetaan pasar. Pelatihan ini secara garis besar ialah program peningkatan kapasitas untuk meningkatkan pengetahuan dan keterampilan anggota organisasi PERTIWI tentang pemasaran produk dan pemetaan pasar untuk menunjuang pengembangan produk kue bapel. Secara subtantif pelatihan dilakukan dengan memberi materi mengenai cara melihat peluang pasar. Disini peneliti memberikan intervensi dengan mengajak peserta untuk menganalisa seberapa besar jaringan yang saat ini telah mereka miliki. Materi selanjutnya membahas cara memasarkan suatu produk. Pada sesi ini peserta diberi skill untuk mengembangkan kemasan dan merk produk, skill promosi dan skill berkomunikasi dengan konsumen atau menawarkan suatu produk, pembuatan tagline produk, pemetaan profil konsumen dan distribusi produk. Tabel 4 
Jurnal Ilmu Sosial dan Pendidikan http://ejournal.mandalanursa.org/index.php/JISIP/index

Terakreditasi Peringkat 5 (No. SK: 85/M/KPT/2020)

adalah output dari kegiatan pelatihan yang berupa hasil pemetaan pasar yang dilakukan secara mandiri oleh para peserta pelatihan

Tabel 4 Hasil Identifikasi dan Pemetaan Pasar Anggota PERTIWI

\begin{tabular}{|c|c|}
\hline $\begin{array}{c}\text { Keterangan/nama } \\
\text { Produk }\end{array}$ & KUE BAPEL \\
\hline Profil Konsumen & $\begin{array}{l}\text { 1. Penduduk lokal } \\
\text { usia } 15-35 \text { semua } \\
\text { kelas sosial. } \\
\text { 2. Pelajar dan } \\
\text { pemuda/i } \\
\text { 3. Pekerja kantoran } \\
\text { 4. Wisatawan }\end{array}$ \\
\hline $\begin{array}{l}\text { Potensi lokasi } \\
\text { distribusi }\end{array}$ & $\begin{array}{l}\text { 1. Institusi } \\
\text { Pendidikan (SD, } \\
\text { SMP, SMA) } \\
\text { 2. Perkantoran } \\
\text { 3. Puskesmas } \\
\text { 4. Pantai Sembilan } \\
\text { (lokasi wisata) } \\
\text { 5. Luar Pulau }\end{array}$ \\
\hline Tagline & $\begin{array}{l}\text { "Makan Bapel, biar } \\
\text { gak baper" }\end{array}$ \\
\hline
\end{tabular}

(Sumber: Data PRA Peneliti, 2020)

Ketiga, program capacity building simulasi inovasi kue bapel dan perumusan SOP kue bapel. Kegiatan ini dilaksanakan dengan menghadirkan seluruh produsen kue bapel beserta anggota organisasi PERTIWI. Simulasi inovasi kue bapel bertujuan agar kue bapel dapat mengakses atau menjangkau konsumen yang lebih luas serta menaikkan harga produk menjadi lebih mahal. Sedangkan perumusan SOP Kue Bapel bertujuan untuk menciptakan standart cita rasa dari kue bapel, sehingga antar pelaku ekonomi bapel satu dengan yang lainnya dapat membuat bapel dengan cita rasa yang sama. Gambar 3 adalah hasil dari inovasi kue bapel, dimana para pemuda sebagai anggota kelembagaan dan pelaku usaha bapel sepakat untuk memberikan inovasi toping dalam setiap
Vol. 4. No. 4 November 2020 p-ISSN: 2598-9944 e- ISSN: 2656-6753

penyajian kue bapel. Berbagai toping yang dicoba dalam agenda simulasi ini berupa toping coklat milo, orep, susu, keju serta campuran. Dengan adanya berbagai toping diharapakan dapat meningkatkan harga jual serta memperluas jaringan konsumen kue bapel.

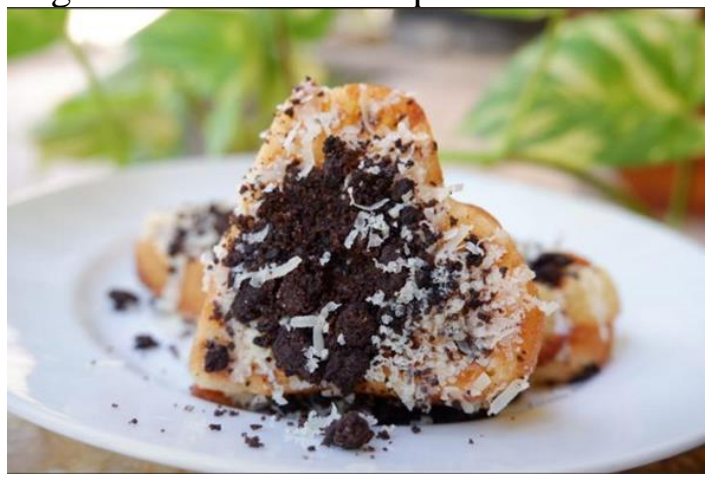

Gambar 6. Hasil Inovasi Produk Bapel

(Sumber: Data PRA Peneliti, 2020)

Selain itu, peneliti juga terlibat dalam inovasi produk, misalnya dengan memberikan bantuan kepada anggota komunitas untuk membuat merk produk, poster promosi dan kemasan baru. Karena sebelumnya produk kue bapel hanya dikemas dengan plastik biasa tanpa merk, sedangkan bapel yang telah diinovasi tidak bisa jika hanya dikemas dengan palstik. Pembuatan poster promosi, merk dan kemasan baru ini diharapkan dapat meningkatkan daya tawar terhadap kualitas produk, sehingga dapat meningkatkan nilai jual produk bapel. Gambar 4 menunjukkan beberapa contoh poster pemasaran yang sudah disertai merk logo 'PERTIWI' sebagai berikut; 


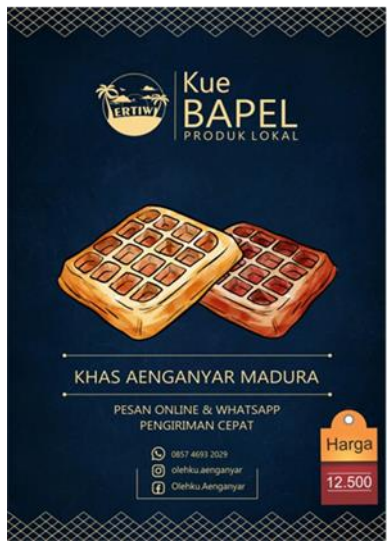

Gambar 7. Poster Pemasaran Produk Bapel

(Sumber: Data PRA Peneliti, 2020)

Setelah SDM sudah dirasa mempunyai kapasitas yang untuk menjalankan sistem kelembagaan dan kualitas produk telah meningkat, kepala desa Aenganyar mengukuhkan organisasi PERTIWI sebagai salah satu program penguatan kelembagaan ekonomi yang bergerak dibidang pengembangan produk lokal non-perikanan dengan penerbitan Surat Keputusan Kepala Desa Aenganyar Nomor: 188/05/KEP/435.309.104/2020 Tentang Pembentukan Pengurus PERTIWI Desa Aenganyar dengan masa bakti 2020-2023. Melalui SK ini telah ditetapkan struktur pengurus serta tugas, pokok dan fungi Lembaga PERTIWI. Selain itu SK ini juga sebagai wujud nyata kehadiran pemerintah desa dalam pengembangan ekonomi lokal non-perikanan di pulau Giligenting. Sebagaimana dalam SK ini juga telah dicantumkan bahwa seluruh biaya yang berkaitan dengan Lembaga PERTIWI dibeban kepada dana Anggaran Pendapatan dan Belanja Desa (APBDES).

Penerbitan SK tersebut telah menjadi pondasi komitmen pemerintah setempat dalam melaksanakan program pembangunan ekonomi lokal. Karena membangun ekonomi lokal dalam kaitannya dengan struktur dan hubungannya

Tabel 5 merupakan gambaran output dari program penguatan kelembagaan ekonomi lokal di Desa Aenganyar, Giligenting, Sumenep. Penelitian ini telah menjadi fasilitator dan dengan pemerintah setempat adalah kunci utama dalam keberhasilan pembangunan ekonomi lokal. Pemerintah setempat penting untuk mengelola secara tepat sumber daya dan kemampuan produksi ekonomi lokal, yang dapat membawa manfaat baik bagi wilayah dan masayarakat lokal di wilayah tersebut. Dengan demikian, pengembangan ekonomi lokal nonperikanan diharapkan dapat berkembang pesat dan menjadi lapangan pekerjaan alternatif bagi masyarakat pesisir di wilayah tersebut.

\section{Hasil Penerapan Program PERTIWI}

Tabel 5 merupakan gambaran output dari Penerapan Model Kelembagaan Ekonomi Sentral melalui Organisasi Pemuda PERTIWI yang telah dilakukan dalam penelitian ini, sebagai berikut;

Tabel 5 Output Penerapan Program PERTIWI

\begin{tabular}{|c|c|c|c|}
\hline \multirow[t]{2}{*}{ No } & \multirow[t]{2}{*}{ Keterangan } & \multicolumn{2}{|c|}{ Output } \\
\hline & & $\begin{array}{c}\text { Sebelum Penerapan } \\
\text { Program }\end{array}$ & $\begin{array}{c}\text { Setelah } \\
\text { Penerapan } \\
\text { Program }\end{array}$ \\
\hline 1. & $\begin{array}{l}\text { Efektifitas } \\
\text { Kegiatan } \\
\text { Ekonomi }\end{array}$ & $\begin{array}{l}\text { Penjualan bapel } \\
\text { belum tersentral } \\
\text { satu merk dan } \\
\text { satu cita rasa. } \\
\text { - Pelaku usaha satu } \\
\text { dan laiinya masih } \\
\text { menerapkan } \\
\text { ekonomi bebas } \\
\text { yang dapat } \\
\text { menciptakan } \\
\text { persaingan antar } \\
\text { penjual. }\end{array}$ & \begin{tabular}{|l} 
- \\
Penjualan \\
bapel telah \\
tersentral satu \\
merk dan satu \\
cita rasa. \\
- \\
Meminimalisir \\
persaingan \\
dengan \\
menerapkan \\
sistem \\
ekonomi \\
kolektif atau \\
komunal. \\
\end{tabular} \\
\hline 2. & $\begin{array}{l}\text { Perkembangan } \\
\text { kualitas produk }\end{array}$ & $\begin{array}{l}\text { - Belum } \\
\text { mempunyai SOP } \\
\text { pembuatan kue } \\
\text { bapel } \\
\text { - Belum ada inovasi } \\
\text { terhadap produk } \\
\text { kue Bapel } \\
\text { - Pengemasan } \\
\text { produk hanya } \\
\text { dengan } \\
\text { menggunakan } \\
\text { plastik biasa tanpa } \\
\text { merk } \\
\text { - Nilai jual rendah } \\
\text { Rp } 10.000 / 10 \\
\text { buah }\end{array}$ & $\begin{array}{l}\text { - Sudah terdapat } \\
\text { SOP } \\
\text { pembuatan } \\
\text { bapel, sehingga } \\
\text { terdapat quality } \\
\text { control pada } \\
\text { produk bapel } \\
\text { - Sudah } \\
\text { dilakukan } \\
\text { inovasi pada } \\
\text { kue bapel } \\
\text { - Pengemasan } \\
\text { produk sudah } \\
\text { menggunakan } \\
\text { kardus dengan } \\
\text { disertai merk } \\
\text { - Nilai Jual } \\
\text { bertambah, Rp. } \\
10.000 / 7 \text { buah } \\
\text { dan Rp } \\
12.500 / 10 \text { buah }\end{array}$ \\
\hline 3. & $\begin{array}{l}\text { Pemasaran } \\
\text { Produk }\end{array}$ & $\begin{array}{l}\text { - Pemasaran hanya } \\
\text { dijual offline di } \\
\text { pasar dsb. } \\
\text { - Pemasaran hanya } \\
\text { menjangkau } \\
\text { wilayah sekitar } \\
\text { atau dalam pulau. }\end{array}$ & $\begin{array}{l}\text { - Pemasaran } \\
\text { sudah dalam } \\
\text { bentuk online } \\
\text { melalui proses } \\
\text { Pre-order di } \\
\text { Media Massa. } \\
\text { - Pemasaran } \\
\text { sudah }\end{array}$ \\
\hline
\end{tabular}

(Sumber: Data PRA Peneliti, 2020)

pendamping secara partisipatif untuk mengidentifikasi potensi, permasalahan hingga penyusunan strategi penyelesaian masalah yang berkaitan dengan pengembangan ekonomi lokal 
Jurnal Ilmu Sosial dan Pendidikan

http://ejournal.mandalanursa.org/index.php/JISIP/index

Terakreditasi Peringkat 5 (No. SK: 85/M/KPT/2020)

non-perikanan. Beberapa output yang dapat dirasakan secara nyata dalam program ini ialah efektifitas kegiatan ekonomi, meningkatnya kualitas produk kue bapel, meluasnya pemasaran dan jaringan konsumen, meningkatnya partisipasi masyarakat yang ikut serta dalam pengembangan produk lokal, meningkatnya omset pelaku usaha dan terbentuknya jaminan bahan baku untuk produk lokal.

Penelitian ini juga telah menunjukan bahwa metode PRA telah berperan secara efektif untuk meningkatkan solidaritas kolektif komunitas masyarakat. Selain itu, metode PRA juga sangat efektif sebagai alat bantu untuk mengeluarkan pengetahuan masyarakat sekitar, ini sebabkan karena PRA menuntuk partisipasi aktif masyarakat untuk mengeluarkan lebih banyak pengetahuan tentang apa yang mereka ketahui, dan bersama-sama membangun pengetahuan lebih dari yang diketahui oleh mereka sendiri secara kolektif (Chambers, 1994b, 1994a). Studi ini menggambarkan bahwa masyarakat lokal dapat berperan secara aktif dalam perumusan program pemberdayaan masyarakat yang akan diterapkan untuk dirinya sendiri. Hal ini hanya bisa terjadi jika peneliti memberi kesempatan kepada masyarakat lokal untuk mengekspresikan, meningkatkan, berbagi serta menganalisis pengetahuan mereka tentang kondisi kehidupan mereka sendiri. Model ini telah meningkatkan kapasitas dan keterampilan masyarakat untuk melakukan penyusunan program pembangunan termasuk meningkatkan kemampuan mereka dalam membuat keputusan untuk menentukan, melakukan dan mencari solusi sehubungan dengan program pemberdayaan mereka sendiri.

\section{KESIMPULAN}

Penelitian ini menunjukkan bahwa berbagai program pembangunan diperlukan untuk memberdayakan masyarakat pesisir, akan tetapi penelitian tidak boleh menolak fakta bahwa masyarakat pesisir tidak hanya terdiri dari seorang nelayan. Pemberdayaan masyarakat
Vol. 4. No. 4 November 2020

p-ISSN: 2598-9944 e- ISSN: 2656-6753 pesisir yang selama ini kebanyakan berbentuk pemberdayaan pada nelayan, sehingga mengabaikan keberadaan komunitas masyarakat lainnya. Selain itu hal ini juga merediksi keberadaan potensi non-perikanan yang dimiliki wilayah pesisir. Oleh karena itu, penelitian ini menunjukan bahwa banyak potensi ekonomi non-perikanan yang dapat dikembangkan sebagai ekonomi alternatif jika itu mampu menghasilkan pendapatan yang besar. Dengan begitu diharapkan mampu menaikan tingkat kesejahteraan masyarakat pesisir.

Penelitian ini dibangun dengan metode Participatory Rural Appraisal yang memberi kesempatan masyarakat untuk mengekplorasi pengetahuannya terhadap kondisi lingkungannya. Hasil penelitian ini menunjukan bahwa masyarakat pulau giligenting mampu mengidentifikasi potensi non-perikanan sekaligus permasalahan yang meliputinya hingga pengembangan potensi sebagai langkah selanjutnya. Masyarakat lokal Giligenting secara efektif juga telah mampu mengoperasionalkan tools social mapping dan tabel analsis SWOT. Dari hasil eksplorasi pengethauan masyarakat tersebut kemudian disusun analisis IFAS-EFAS untuk menentukan strategi progam pengembangan ekonomi lokal non-perikanan. Dari hasil analisi IFAS-EFAS kemudian ditemukan strategi untuk mengatasi permasalahan terkait pengembangan usaha bapel sebagai slaah satu produk non-perikanan yang ada di Giligenting. PERTIWI merupakan organisasi pemuda yang telah didirikan untuk menjawab permasalahan terkait pengembangan ekonomi lokal non-perikanan. Tujuan utama organisasi ini adalah untuk melakukan penguatan kelembagaan ekonomi non-perikanan dengan cara mengoptimalkan efektifitas ekonomi serta kualitas dan pemasaran produk ekonomi lokal. Penerapan model kelembagaan PERTIWI telah menghasilkan beberapa output, diantaranya meningkatkan efektifitas kegiatan ekonomi, meningkatkan kualitas produk kue bapel, memperluas pemasaran dan jaringan konsumen, meningkatkan partisipasi masyarakat 
Jurnal Ilmu Sosial dan Pendidikan

http://ejournal.mandalanursa.org/index.php/JISIP/index

Terakreditasi Peringkat 5 (No. SK: 85/M/KPT/2020)

yang ikut serta dalam pengembangan produk lokal, meningkatkan omset pelaku usaha dan terbentuknya jaminan bahan baku untuk produk lokal.

\section{UCAPAN TERIMA KASIH}

Secara khusus peneliti mengucapkan terima kasih kepada Lembaga Penelitian dan Pengembangan Masyarakat (LPPM) Universitas Brawijaya yang telah mendanai kegiatan pengabdian ini melalui Skema Program Hibah Doktor Mengabdi Tahun 2020.

\section{DAFTAR PUSTAKA}

Alaerts, G. J. (2009). Knowledge and capacity development (KCD) as tool for institutional strengthening and change. Water for a Changing World - Developing Local Knowledge and Capacity - Proceedings of the International Symposium on Water for a Changing World, 5-26. https://doi.org/10.1201/9780203878057.ch 2

Amanah, S. (2010). Peran Komunikasi Pembangunan dalam Pemberdayaan Masyarakat Pesisir. Jurnal Komunikasi Pembangunan, $8(1), \quad 245896$. https://doi.org/10.29244/jurnalkmp.8.1.\%p

Bar-on, A. A., \& Prinsen, G. (1999). Planning, communities and empowerment: An introduction to participatory rural appraisal. International Social Work, 42(3), 277-294. https://doi.org/10.1177/002087289904200 303

Chambers, R. (1994a). Participatory rural appraisal (PRA): Analysis of experience. World Development, 22(9), 1253-1268. https://doi.org/10.1016/0305750X(94)90003-5

Chambers, R. (1994b). Participatory rural appraisal (PRA): Challenges, potentials and paradigm. World Development, 22(10), 1437-1454. https://doi.org/10.1016/0305750X(94)90030-2

Chambers, R. (1994c). The Origins and Practice of Participatory Rural Appraisal. World
Vol. 4. No. 4 November 2020

p-ISSN: 2598-9944 e- ISSN: 2656-6753

Development, 22(7), 953-969.

Daniarsyah, D. (2019). Efektivitas Pelaksanaan Kebijakan Program Kartu KUSUKA pada Kementrian Kelautan dan Perikanan. Journal of Indonesian Public Administration and Governance Studies, 628-643.

Eade, D. (1997). Capacity Building: An approach to people centered development. Oxford: Oxfam.

Eade, D. (2007). Development in Practice Capacity building: who builds whose capacity? Development in Practice, 17(45), 630-639.

Herbert, R., \& Irene, S. R. (1992). Community Organizing and Developmen. New York: Macmillan.

Heriyanto, M. (2013). Evaluasi Program Pemberdayaan Ekonomi Masyarakat Pesisir. Kebikanan Publik, 4(1), 1-118.

Indarti, I., \& Wardana, D. S. (2013). METODE PEMBERDAYAAN MASYARAKAT PESISIR MELALUI PENGUATAN KELEMBAGAAN DI WILAYAH PESISIR KOTA SEMARANG. BENEFIT Jurnal Manajemen Dan Bisnis, 17(1), 7588.

Irwanto. (1998). Focus Group Discussion (FGD) Sebuah Pengantar Praktis. Jakarta: Pusat Kajian Pembangan Masyarakat Universitas Atmajaya.

Jacobs, C. (1998). Institutional strengthening and technical co-operation: developing a best practice model. Journal of International Development, 10(3), $397-$ 406. https://doi.org/10.1002/(SICI)10991328(199805/06)10:3<397::AIDJID515>3.0.CO;2-H

Kurniasari, N., \& Reswati, E. (2011). Memaknai Program Pemberdayaan Ekonomi Masyarakat Pesisir. Buletin Ilmiah Marina Sosial Ekonomi Kelautan Dan Perikanan, 6(1), 7. https://doi.org/10.15578/marina.v6i1.5805

Kurniyati, Y. (2013). Penguatan Kapasitas Kelembagaan Kelompok PEW untuk 
Jurnal Ilmu Sosial dan Pendidikan

http://ejournal.mandalanursa.org/index.php/JISIP/index

Terakreditasi Peringkat 5 (No. SK: 85/M/KPT/2020)

Pengembangan Ekonomi Lokal Kota Yogyakarta. Jurnal Maksipreneur: Manajemen, Koperasi, Dan Entrepreneurship, $\quad 3(1), \quad 91$. https://doi.org/10.30588/jmp.v3i1.90

Nikijuluw, V. P. H. (2001). Populasi dan Sosial Ekonomi Masyarakat Pesisir Serta Stategi Pemberdayaan Mereka Dalam Konteks Pengelolaan sumberdaya Pesisir Secara Terpadu. In Makalah Pelatihan Pengelolaan Pesisir Terpadu, Institut Pertanian Bogor (Vol. 1).

Nowakowska-Grunt, J., \& Wiśniewska-Sałek, A. (2014). Managing the local economy on the example of the construction sector companies. Advanced Materials Research, 1020 , 783-788. https://doi.org/10.4028/www.scientific.net /AMR.1020.783

Rahim, A. (2018). The Empowerment Strategy of the Traditional Fisherman'S Wives in the Coastal Area of Barru Regency, South Sulawesi. Journal of Socioeconomics and Development, $\quad 1(1), \quad 1-6$. https://doi.org/10.31328/jsed.v1i1.515

Rockloff, S., \& Lockie, S. (2004). Participatory tools for coastal zone management. Journal of Coastal Conservation, 10, 81-92.

Sakinah, N., Adiputra, Y. S., \& Outri, N. A. D. (2018). EVALUASI PROGRAM BANTUAN PREMI ASURANSI NELAYAN (BPAN) DI KECAMATAN BINTAN TIMUR KABUPATEN BINTAN TAHUN 2018. Gastrointestinal Endoscopy, 10(1), 279-288. Retrieved from

http://dx.doi.org/10.1053/j.gastro.2014.05. 023\%0Ahttps://doi.org/10.1016/j.gie.2018. 04.013\%0Ahttp://www.ncbi.nlm.nih.gov/p ubmed/29451164\%0Ahttp://www.pubmed central.nih.gov/articlerender.fcgi?artid=P MC5838726\%250Ahttp://dx.doi.org/10.10 16/j.gie.2013.07.022

Solano Lara, C., Fernández Crispín, A., \& López Téllez, M. C. (2018). Participatory rural appraisal as an educational tool to empower
Vol. 4. No. 4 November 2020

p-ISSN: 2598-9944 e- ISSN: 2656-6753

sustainable community processes. Journal of Cleaner Production, 172, 4254-4262. https://doi.org/10.1016/j.jclepro.2017.08.0 72

Susanto, V. Y. (2019, September 12). Hingga Agustus 2019, KKP salurkan asuransi nelayan sebanyak Rp 388 miliar. Kontan.Co.Id. Retrieved from https://nasional.kontan.co.id/news/hinggaagustus-2019-kkp-salurkan-asuransinelayan-sebanyak-rp-388-miliar

Tampubolon, D. (2013). Strategi Pemberdayaan Masyarakat Pesisir Di Kabupaten Kepulauan Meranti. Sorot, 8(2), 153. https://doi.org/10.31258/sorot.8.2.2358

Taranova, I. V., Gunko, A. Y. yevich, Alekseeva, O. A. evna, Bunchikov, O. N., \& Kurennaya, V. V. evna. (2015). Development of methodical approach on identification of cluster forms of the organization of economy of the traditional and agrarian region. Asian Social Science, 11(14), 95-103. https://doi.org/10.5539/ass.v11n14p95

Taylor, P. S., \& Cowiconsult. (1998). Institutional strengthening. In Highway and Traffic Engineering in Developing Countries.

https://doi.org/10.4324/9780203223673_c hapter_24

Tiven, M., Huliselan, N. V, \& Lopulalan, Y. (2018). EFEKTIVITAS KEBIJAKAN KARTU NELAYAN KOTA AMBON ( Effectiveness of Fisfermen Card Policies in Ambon City ) Berdasarkan data Badan Pusat Statistik. Jurnal TRITON, 14(2), 7687.

Yoeti, O. (1996). Pengantar Ilmu Pariwisata. Bandung: Angkasa.

Yusman, S., \& Atmaja, H. kusuma. (2004). Pengembangan Ekonomi Lokal Berbasis Lokal. Bogor: MPPM IPB.

Zamzami, L. (2011). Model Pemberdayaan Ekonomi Masyarakat Pesisir. MIMBBAR, XXVII(1), 113-125. 